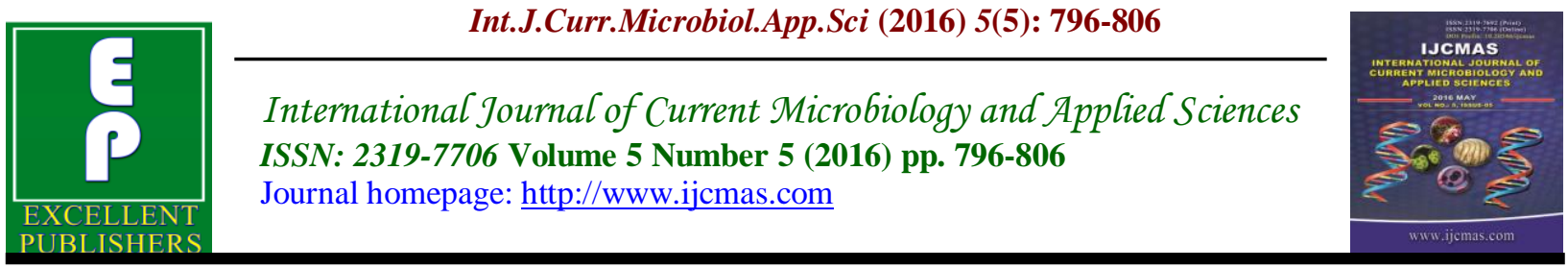

Original Research Article

http://dx.doi.org/10.20546/ijcmas.2016.505.080

\title{
Effects of stone crusher dust pollution on growth performance and yield status of rice (Oryza sativa. L)
}

\author{
Shashi Bhushan Sharma and Baidyanath Kumar* \\ Department of Botany and Biotechnology, College of Commerce \\ (Magadh University), Patna, India \\ *Corresponding author
}

\begin{abstract}
A B S T R A C T
Keywords

Stone crusher dust, pollution,

Oriza sativa, seedling growth, chlorophyll, protein, carbohydrate.

Article Info

Accepted:

20 April 2016

Available Online:

10 May 2016

In the present investigation the effect of stone crushing dust pollution on the growth performance and yield status of Rice (Oryza sativa) was studied in specified land areas of village Arap, Patna. The results indicated that the germination frequency of seeds, shoot length, root length, chlorophyll content, total carbohydrate and protein contents, and grain yield of Rice (Oryza sativa) were severely affected by stone dust pollution. The treated seeds showed only 68 to 70 $\%$ germination in comparison to control $(85 \%)$. The chlorophyll content in stone dust treated seedlings was found to be less (Chl-a $65 \mathrm{mg} / \mathrm{g}$ and $18.75 \mathrm{mg} / \mathrm{g}$ of leaf tissue in comparison to control (chl-a 90.75 and chl-b $25.25 \mathrm{mg} / \mathrm{g}$ of leaf tissue). The total carbohydrate was also less, $115.35 \mu \mathrm{g} / 100 \mathrm{mg}$ of leaf tissue in comparison to control $(127.25 \mu \mathrm{g} / 100 \mathrm{mg}$ of leaf tissue). The total protein was less in the range of 94.75 to $96.15 \mathrm{mg} / \mathrm{gm}$ of leaf tissue in comparison to control $(103.50 \mathrm{mg} / \mathrm{gm}$ of leaf tissue). The yield status of treated plants was significantly declined to115.50 $116.65 \mathrm{gm} /$ plant in comparison to control $125 \mathrm{gm} / \mathrm{plant}$ ). The plants that grown in control land area were healthy as compared to plants grown in the stone dust treated land areas. A loss in chlorophyll-a and chlorophyll-b content in leaves of plants treated with stone dust supported the argument that the chloroplast is the primary site of attack by stone crushing dust pollutants. The present results clearly indicate that the stone crushing dust adversely affect the growth and yield status of Rice (Oryza sativa).
\end{abstract}

\section{Introduction}

There are three main categories of stones, siliceous, argillaceous and calcareous. The siliceous stone is made up of silica or silicon dioxide $\left(\mathrm{SiO}_{2}\right)$. This type of stone also includes compressed sediments like sandstones viz. quartz (pressurized sand stone), mica, feldspar etc. The average density of granite is between 2.65 and $2.75 \mathrm{~g} / \mathrm{cm} 3$, its compressive strength lies above 200Mpa, and its viscosity near STP is 3-6.1019paS (Kumagai et al., 1978). Its melting temperature is 1215-12600C (American Mineralogist, 1929). The argillaceous stone is basically composed of alumina (A12O3). Calcareous stone is made up mostly of calcium carbonate $\left(\mathrm{CaCO}_{3}\right)$ or lime which comes from the bodies of sea creatures. 
The world wide average chemical composition of stone/granite by weight percent, based on analysis of Harvey Blatt and Robert J. Tracy, 1997 is as follows:

$\mathrm{SiO}_{2}-72.04 ; \mathrm{Al}_{2} \mathrm{O}_{3}-14.42 ; \mathrm{K}_{2} \mathrm{O}-4.12 ; \mathrm{Na}_{2} \mathrm{O}-$ 3.69; CaO-1.82; FeO3-1.22; MgO-0.71; $\mathrm{TiO}_{2}-0.30 ; \mathrm{P}_{2} \mathrm{O} 5-0.12$ and $\mathrm{MnO}_{2}-0.05$

There are over 12000 stone crusher units operating in India (Patil, 2001). Clusters of stone crushing and sizing units are located at Pakur district, Jharkhand. The stone crushing industry and the associated traffic in this area generate a number of air pollutants which exceed the air quality standards, particularly during day time. The stone crushing industry at Pakur District includes two main operations: quarrying or mining operations and crushing operations. But, there is a lack of environmental governance in both quarries and the crushers which has resulted in considerable degradation of the environment surrounding the locations where stone crushing industry is established (ES, 1998).

The suspended particulate matter (SPM) released due to stone crushing, remain in the air for varying length of time. Those larger than $10 \mu \mathrm{m}$ in size settle under the force of gravity on the vegetations and soil but the smaller ones remain suspended in air for longer periods of time, get dispersed and diffused by wind, and eventually deposited on various surfaces including foliar ones (Rao, 1971; Rao, 1985).

Stone dust is a primary aerosol and it is released directly from the source. This primary aerosol has a detrimental effect on people and environment including flora and fauna, for example changed soil $\mathrm{pH}$ and productivity, formation of haze reducing visibility in the surrounding areas, destruction of habitat, damage of natural resources like valuable vegetations and wild lives, promotion of spreading many diseases etc. (Semban and Chandrashekhar, 2000; Das and Nandi, 2002; Mishra, 2004; Siva coumar et al., 2006).

Effects of cement, petroleum- cake dust, flyash, coal dust, automobile exhaust and other air borne particulates on various morphological and physiological parameters in different plants were studied by many workers viz. Singh and Rao, 1980; Prasad and Rao, 1981; Ambrust, 1986; Agrawal and Agrawal, 1989; Pyatt and Haywood, 1989; Naidu and Chirkut, 2004; Verma and Singh, 2006; Prajapati and Tripathi, 2008; Pandey and Kumar, 1996; Pandey and Sinha, 2000; Grewal et al., 2001; Pandey and Kumar, 2004; Mishra, 2008; Mishra and Kumari, 2008; Pandey et al., 2008; Pandey et al., 2009; Pandey and Prasad, 2010; Prasad et al., 2010; Pandey and Pandey, 2010; Kumari and Pandey, 2011; Saha and Pandey, 2011 etc.

Agricultural crops have long been act as a sink for air pollutants and to suffer from the harmful consequences. Reduction of ascorbic acid, protein, carbohydrate and pigments was noticed by Prasad and Rao (1981) in petroleum- coke treated plants, Phaseolus aureus. Reduction of dry weight in Gossypium hirsutum due to reduced photosynthesis as a result of dust deposition was studied by Ambrust (1996). The growth and development aspects of plants are adversely affected by air- borne particulates, depending on their physical and chemical nature. John and Iqbal (1992) observed reduction in the leaf blade area of five tree species as a result of extensive dust and $\mathrm{SO} 2$ pollution. Most of the plants experience physiological alterations before morphological injury symptoms become visible on their leaves (Liu and Ding, 2008). Prajapati and Tripathi (2008) studied species- wise and season- wise dust deposition pattern on six selected tree 
species and their effects on chlorophyll and ascorbic acid content in foliar tissues. Dulalchandra Saha and Pratap Kumar Padhy (2011) have studied the effects of stone crushing industry on Shorea robusta and Madhuca indica foliage. Investigations on ten annual plant species by Rai et al., (2010) reveals that the foliar surface was an excellent receptor of atmospheric pollutants leading to a number of structural and functional changes.

Rice (Oryza sativa L.) belongs to the tribe Oryzeae of the subfamily Pooideae of family Gramineae. This cereal crop is distributed in the tropical and subtropical regions of Africa, Asia, Australia and South America. The African continent is usually considered to be the centre of origin of the genus Oryzae.

Rice is the only cereal that is largely consumed whole by man as harvested (after dehulling and polishing) and is usually simply boiled for direct consumption. Over one- half of the world's population subsists wholly or partially on rice. It is the principal food of the Far East where, in fact, meat, fish, fowl, vegetables, pulses and condiments are considered only as garnishes for the main dish of rice.

Rice is grown over acreage of about 137 million hectares in the tropical and subtropical parts of the world. Over 85 per cent of the world's rice production comes from China, India, Bangladesh, Japan, Pakistan and the adjoining islands in the Pacific. China leads in the world production accounting for approximately $115200000 t$.

India has the largest area under rice cultivation, with 38 million hectares (about 28 per cent of the total world acreage) yielding about 44000000t. The leading rice producing states in India are West Bengal,
Tamil Nadu, Andhra Pradesh, Orissa, Bihar, Uttar Pradesh, Madhya Pradesh and Assam.

The rice plant is a semi- aquatic, free tillering annual grass with a cylindrical jointed stem (culm), about $50-150 \mathrm{~cm}$ tall, but may go up to $5 \mathrm{~m}$ in floating rices. The internodes are shortest at the base, becoming progressively longer. Above each node, there is a pronounced thickening 'pulvinus' with an intercalary meristem. Rice has a shallow root system, its extent being controlled by the nature of the soil and the water supply. The first leaf at the base of the main culm and each tiller is rudimentary, consisting of a bladeless 'prophyllum'. The leaves are borne alternately on the stem in two ranks- one at each node, each consisting of leaf sheath, leaf blade, ligule and auricles, the former encircling the whole or part of the internodes. At the junction of the leaf sheath and leaf blade, there is a triangular membranous, usually colorless ligules that tends to split with age and is flanked on either side by a small sickle-like appendage, fringed with long hairs (auricles). The leaf blade is long, narrow, $30-50 \mathrm{~cm}$ or more in length and 1-2 cm broad and somewhat pubescent having spiny hairs on the margins. The lamina of the uppermost leaf below the panicle is wider and shorter than the others.

The rice inflorescence is a loose terminal panicle, $7.5-38.0 \mathrm{~cm}$ long. The spikelets are usually borne singly, but clustered forms with two to seven spikelet together are known. Each spikelet is laterally compressed and one-flowered, borne on a short pedicel and is subtended by two diminutive sterile glumes that are lanceolate, leathery, shiny structures ranging in color from white, yellow to red or black. The flower is usually self pollinated and is surrounded by a lemma and palea that make up the hull or husk and remains attached to the grains in threshing. 
The lemma is tough, papery and may be fully awned, partially awned or awnless, while the palea is somewhat smaller, sometimes awned. Enclosed within the lemma and palea are two broad, thick, fleshy lodicules, six stamens in two alternating whorls, and a pistil with two plumose stigmas on two style.

The mature rice grain is a caryopsis. Rice invested in the hull is called 'rough rice' or 'paddy', while that with hull removed is known as 'brown', 'husked' or 'cleaned' rice. Rough rice consists of about 20 per cent hull. The grain coat is often pigmented and is differentiated into epicarp, mesocarp, cross cells, tube cells and spermoderm or integument. The remnents of the nucellar tissue are present just underneath the integument. The endosperm consists of a single aleurone layer of polygonal cells with a central mass of thin walled parenchymatous tissue containing mostly starch.

The embryo is located near the base towards the lemma of ventral side of the grain and consist of strongly differentiated scutellum, plumule and radicle. The plumule is ensheathed by the coleoptiles and radicle by the coleorhiza.

The pericarp, nucellus, aleurone layer and the embryo (germ) collectively constitute the 'bran' which is quite rich in oils, proteins, mineral salts and vitamins; but most of the nutritional part are lost during the milling operation.

The rice crop is grown over an extremely wide range of climatic conditions extending from 490N (in Czechoslovakia) to $400 \mathrm{~S}$ latitude, and from sea level or even below to $3000 \mathrm{~m}$ in the Himalayas. For the satisfactory production of rice the following prerequisites must be satisfied:
1. A relatively high temperature during the growing season;

2. An abundant and dependable source of water for irrigation;

3. A close textured or relatively impervious subsoil to prevent excessive lose of water by seepage and

4. Provision for steady surface drainage to allow the land to dry out sufficiently for harvesting.

The cultivated varieties differ a great deal from each other in their season of growth, maturation period, suitability to varying conditions of soils, temperature, rainfall, altitude and adaptability to each special environments such as flooded land, alkalinity and acidity of soil and depth of standing water.

Rice can be grown on many types of soil from sandy loams and shallow lateritic soil to heavy clay, but heavy alluvial soils of river valleys and deltas are preferable. The crop is able to tolerate a wide range of soil reactions, but it does have a preference for acidic soils.

The rice crop thrives best under conditions of high temperature and humidity, the average temperature during the growing phase ranges between 21 and 350C.

\section{Materials and Methods}

Patna is the capital of Indian state Bihar. Its total area is approximately $3202 \mathrm{~km}^{2}$ and is situated at altitude 53m, 25 $36^{\prime} 40^{\prime \prime}$ North latitude, $85^{\circ} 08^{\prime} 38^{\prime \prime}$ East longitudes. The climate is generally dry and humid with four distinct seasons, viz. summer, rainy, winter and spring. The maximum and minimum temperatures recorded during summer and winter respectively are $42^{\circ} \mathrm{C}$ and $50^{\circ} \mathrm{C}$. The annual rainfall is about $1450 \mathrm{~mm}$ and the maximum relative humidity is $90 \%$ during rainy season. 
The present work was carried out in the Biochemistry research laboratory, Dept. of Biotechnology, College of Commerce, Patna from November 2014 to December 2014 and in field from October 2015 to January 2016.

The field work was carried out on agriculturally fertile soil of village Arap, District Patna. Six specified land area, each of an area of about $5 \mathrm{~m} 2$ were selected (one for control and five for treatment) as follows:

Control: Area not treated with stone crushing dust

SA1: Area where pulses crops are being grown

SA2: Area where cereal crops are being grown

SA3: Area where both cereal and pulses crops are being grown

SA4: Area where vegetable crops are being grown

SA5: Area where oil yielding crops are being grown

Seeds (about 200g) of Paddy (Oryza sativa. L) were sown separately in each of the specified land area. Stone crushing dust (about 100g) collected in polythene bag in the vicinity of stone crusher mills of Pakur District Jharkhand was dusted on the plantation fields at the time of sowing seeds. One of the six fields was treated as control. The percentage of germination of seeds was recorded in all fields. Similarly growth of the seedlings one week after seed germination in each specified land area was recorded in terms of root and shoot lengths.

One month after germination ten fresh leaves were collected from each specified land area and subjected to biochemical analysis in laboratory. The chlorophyll was extracted in $80 \%$ (v/v) aqueous acetone. The extract was centrifuged at 2000rpm. The absorbance was recorded at 645 and $663 \mathrm{~nm}$ using a spectrophotometer. Chlorophyll-a and chlorophyll-b were assayed by the method suggested by Arnon (1949) and expressed in $\mathrm{mg} / \mathrm{g}$ of leaf tissue. The total carbohydrate was measured following Anthrone method suggested by Hedge and Hofreiter (1962) and was expressed in $\mu \mathrm{g} / 100 \mathrm{mg}$ leaf tissue. The foliar protein content was expressed by method suggested by Lowry et al., (1951) and expressed in $\mathrm{mg} / \mathrm{g}$ of leaf tissue. The yield was measured in terms of gm of grain/plant in fields after 100 days of cultivation and the results were analyzed statistically by one way analysis of variance (ANOVA). The results obtained have been presented in Table-1, 2, 3 and 4.

\section{Results and Discussion}

The germination behavior of seeds of Rice (Oryza sativa) was analyzed at five different specified land areas of Arap village, Patna when sols of each land area were previously treated with $100 \mathrm{gm}$ of stone dust. The results showed that the germination percentage of gram seeds was low in all the five specified land areas as compared to control. The control field favoured $85 \%$ germination. Among stone dust treated soils the percentage of germination was maximum in SA1, followed by SA5, SA3, SA2 and SA4 (Table-1).

The seedling growth of gram was also lower in all the specified land areas as compared to control field (Table-2). In control field the shoot and root lengths were found to be $16.7 \mathrm{~cm}$ and $10.5 \mathrm{~cm}$ respectively one month after germination. In all the five stone dust treated areas seedling growth was relatively low, in the range of 12.0 to $12.6 \mathrm{~cm}$ shoot length and 9.5 to $10.5 \mathrm{~cm}$ root lengths. The 
present findings gain support from the work of ShashuBhushan and Baidyanath (2015) who also observed a decrease in shoot and root lengths in Cicer arietinum on treatment of stone crushing dust. Sadhana Chaurasia et al., (2014) also observed a decrease in shoot and root lengths in Wheat (Triticum species) in response to particulate pollutants released near the Cement industry of Kodinagar, Gujarat. Chouhan and Joshi (2010) found that the plants growing at $0.5 \mathrm{~km}$ distance from Cement industry have lesser growth (root and shoot length) and as the distance increases from the industry the shoot length and root length also increases. Decrease in plant height of Cow pea was also recorded along the gradient of air pollution by Addo et al.,(2013).

The plants grown in all the stone dust treated land areas showed thick root systems, stunted growth with stubby and brittle branches as compared to control plants. These symptoms might be due to toxic effects of aluminium which is present in the form of alumina (Al2O3) in 14.42 percent. Therefore in view of the environmentally prevalent nature of aluminium compounds its levels should be regularly monitored to avoid toxicity caused by this soil pollutant.

Results of the present investigation showed reduction in foliar chlorophyll, total carbohydrate and protein content in the stone dust treated land areas which indicated that the process of manufacturing food by Oryza sativa was reduced as a result of stone dust pollution (Table-3). In control field the foliar chlorophyll-a and chlorophyll-b were $90.75 \mathrm{mg} / \mathrm{g}$ and $25.22 \mathrm{mg} / \mathrm{g}$ of total leaf tissue respectively. Among stone dust treated specified land areas the foliar chlorophyllawas maximum in SA2 and SA5 (75.15mg/g), followed by SA3 $(70.35 \mathrm{mg} / \mathrm{g})$ and minimum in SA4 $(64.30 \mathrm{mg} / \mathrm{g})$ and SA1 $(65.50 \mathrm{mg} / \mathrm{g})$. The chlorophyll-b content was minimum in SA2 $(16.18 \mathrm{mg} / \mathrm{g})$ and $\mathrm{SA} 1$ $(16.75 \mathrm{mg} / \mathrm{g})$. In SA3, SA4 and SA5 the chlorophyll-b content was more or less similar, in the range of 18.25 to $18.92 \mathrm{mg} / \mathrm{g}$ of foliar tissue.

In all the stone dust treated specified land areas the foliar protein and carbohydrate contents were also found to be low as compared to the control. The total foliar protein content was in the range of 94.75 to $96.15 \mathrm{mg} / \mathrm{g}$ of leaf tissue in the stone dust treated plants as compared to control (103.50mg/g of leaf tissue). Similarly the total foliar carbohydrate in treated plants was in the range of 114.75 to $115.75 / 100 \mu \mathrm{g}$ of leaf tissue in comparison to control $(127.25 \mu \mathrm{g} / 100 \mathrm{mg}$ of leaf tissue). The present findings are in accordance with DulalChandra Saha and Pratap Kumar Padhy (2011) who also observed the decline in chlorophyll-a, chlorophyll-b, total carbohydrate and protein contents in Shorea robusta and Madhuca indica when their foliages were treated with stone crushing dust pollutants. ShashiBhushan Sharma and Baidyanath Kumar also observed a more or less similar results in Gram (Cicer arietinum) in stone dust treated experiment. Singh and Rao (1980) found incidence of foliar injury symptoms and decrease in concentration of chlorophyll in plants in the vicinity of Cement factories. Prasad and Rao (1981) found decrease in protein and carbohydrate content in petroleum coke treated plants. Agarwal and Agarwal (1989) found reduction in photosynthetic pigment in Mangifera indica around a thermal power plant. 
Table.1 Showing Percentage Germination of Seeds of Rice (Oryza sativa) after Treatment of Stone Dust.

\begin{tabular}{|l|l|}
\hline Treatment & Percentage germination \\
\hline Control land area & 85 \\
\hline SA1 & 70 \\
\hline SA2 & 68 \\
\hline SA3 & 67 \\
\hline SA4 & 68 \\
\hline SA5 & 65 \\
\hline
\end{tabular}

Table.2 Seedling Growth of Rice (Oryza sativa) One Month after Treatment with Stone Dust

\begin{tabular}{|l|c|c|}
\hline Treatment & Root length in $\mathrm{cm}^{\mathrm{a}}$ & Shoot length in $\mathrm{cm}^{\mathrm{a}}$ \\
\hline Control land area & $10.5 \pm 0.13$ & $16.7 \pm 0.14$ \\
\hline SA1 & $10.2 \pm 0.14$ & $12.6 \pm 0.81$ \\
\hline SA2 & $10.5 \pm 0.16$ & $12.2 \pm 0.07$ \\
\hline SA3 & $9.6 \pm 0.06$ & $12.5 \pm 0.13$ \\
\hline SA4 & $9.5 \pm 0.08$ & $12.4 \pm 0.16$ \\
\hline SA5 & $9.8 \pm 0.11$ & $12.0 \pm 0.15$ \\
\hline
\end{tabular}

$a=$ average of 10 replicates: $p$ at 0.05 level

Table.3 Showing Biochemical Characteristics of Foliage of Rice (Oryza sativa) After Treatment with Stone Dust

\begin{tabular}{|l|l|l|l|l|l|l|}
\hline $\begin{array}{l}\text { Biochemical } \\
\text { parameters }\end{array}$ & Control & SA1 & SA2 & SA3 & SA4 & SA5 \\
\hline Chl-a & 90.75 & 65.50 & 70.15 & 70.35 & 64.30 & 70.15 \\
\hline Chl-b & 25.25 & 16.75 & 16.18 & 18.36 & 18.25 & 18.92 \\
\hline Total carboh & 127.25 & 115.16 & 115.35 & 115.45 & 115.75 & 114.75 \\
\hline Protein & 103.50 & 95.15 & 94.75 & 96.15 & 95.16 & 95.50 \\
\hline
\end{tabular}

Chl-a and chl-b in $\mathrm{mg} / \mathrm{g}$ of leaf tissue; carbohydrate in $\mu \mathrm{g} / 100 \mathrm{mg}$ of leaf tissue; total protein $\mathrm{mg} / \mathrm{g}$ of leaf tissue

Table.4 Showing Grain Yield in G/Plant Of Rice (Oryza sativa after Three Months.

\begin{tabular}{|l|l|}
\hline Treatment & Grain yield $^{\mathrm{a}}$ in $\mathrm{gm} / \mathrm{plant}$ \\
\hline Control & $115.50 \pm 1.25$ \\
\hline SA1 & $115.75 \pm 0.16$ \\
\hline SA2 & $115.55 \pm 0.11$ \\
\hline SA3 & $116.50 \pm 0.13$ \\
\hline SA4 & $117.65 \pm 0.14$ \\
\hline SA5 & $117.45 \pm 0.15$ \\
\hline
\end{tabular}

$\mathrm{a}=$ average of 10 replicates; $\mathrm{p}$ at 0.05 level 
Pandey and Nand (1995) assessed the effect of stone crusher dust on grain characteristics of Maize and found lower values of protein as compared to control. Trivedi and Singh (1995) noticed significant reduction in protein content in few plants as a result of fly ash particulates. Williams and Banerjee (1995) found considerable reduction in chlorophyll and protein in leaves of Mangifera indica and Shorea robusta affected by emissions from a nearby thermal power plant. Marked alterations in photosynthetic pigments and protein content in foliar tissues as a result of auto exhaust pollution were noticed by Verma and Singh (2005). Similarly, decrease in chlorophyll content as a result of increased dust deposition was noticed by Prajapati and Tripathi (2008).

After 100 days of plantation plants were harvested from all the treated and control land areas separately and grain yield per plant was statistically analyzed. The result showed that there was a marked reduction in the grain yield in stone dust treated land areas ( 115.50 to $116.75 \mathrm{~g} /$ plant) as compared to control in which grain yield per plant was recorded to $125.50 \mathrm{~g} /$ plant (Table-4). The present finding gains support from the work of Sadhana Chaurasia et al., (2014) who also found a marked reduction in the grain yield and grain weight in Triticum species on account of the impact of cement industry pollution. ShashiBhushan Sharma and Baidyanath Kumar (2015) have observed a similar results in Cicer arietinum after treatment of stone dust. All the statistically data show that the result was significant at 95\% level.

The results obtained in the present investigation indicate that the shoot length, root length, chlorophyll content, total carbohydrate and protein contents, and grain yield of Rice (Oryza sativa) were severely affected by stone dust pollution. The plants growing in control land area were healthy than the plants growing in the stone dust treated land areas. A loss in chlorophyll-a and chlorophyll-b content in leaves of plants treated with stone dust supports the argument that the chloroplast is the primary site of attack by stone crushing dust pollutants. The present results clearly indicate that the stone crushing dust adversely affect the growth and yield status of Rice (Oryza sativa).

\section{Acknowledgment}

The first author is grateful to Dr. Baidyanath Kumar, Visiting Professor, Department of Biotechnology, College of Commerce (Magadh University), Patna for providing necessary suggestions.

\section{References}

Addo, M. A, Darko e. O, Gordon, C and Nyarko, B. J. B (2013): Contribution of soils and loss of productivity of Cowpea (Vigna unguiculata L.) caused by cement dust pollution, Inter. J. Res. In Chem. And Env. 3(1): 272- 282.

Agrawal, M and Agrawal, S. B (1989): Phytomonitoring of air pollution around thermal power plant, Atmospheric Environment, 23, 263769.

Arnon, D. I (1949): Copper enzyme in isolated chloroplasts polyphenol oxidase in Beta vulgaris, Plant Physiology, 24, 1- 15.

Ambrust, D. V (1986): Effect of particulate dusts on cotton growth, photosynthesis and respiration, Agronomy Journal, 78, 1078- 1081.

Chauhan, A and Joshi, P. C. (2010): Effect of ambient air pollutants on wheat and mustard crops growing in the vicinity 
of urban and industrial areas, New York, Science J. 3(2): 52- 60.

Das, D. K and Nandi, A (2002): Health hazard in stone quarries and crushers. Science and Technology project, Government if India, NISM, Kolkata.

Dulal Chandra Saha and Pratap Kumar Padhy (2011): Effects of stone crushing industry on Shorea robusta and Madhuca indica foliage in Lalpahari forest, Atmospheric pollution Research, 2, 463- 476.

E S (1998): Excutive summary of the Report on the state Environment, "Status of environment in West Bengal", PartII. Vectors of Environmental Impacts, The Department of environment Government of West Bengal in September, 1998.

Grewal, K. S, Yadava, P. S, Mehta, S. C. and Oswal, M. C. (2001): Direct and residual effect of fly ash application to soil on crop yield and soil properties. Crop. Res. 21: 60- 65

Harvey Blatt and Robert J. Tracy (1997): Petrology (2nd ed.). New York Freeman P. 66.

Hedge, J. E and Hofreiter, B. t (1962): In: Carbohydrate chemistry 17 (Eds Whistler, R. L. and Be Miller, J. N), Academic Press, New York.

John, $S$ and Iqbal, M. Z (1992): Morphological and anatomical studies on leaves of different plants affected by motor vehicle exhaust. Journal of Islamic Academy of Sciences, 5, 2123.

Kumagai, Naoichi, Sodao Sasajima, HidebumiIto (1978): "Long- term creep of Rocks; Results with Large specimens obtained in about 20 years and Those with small specimens in about 3 years". Journal of the Society of Materials Science, Japan (Japan Energy Society) 27 (293): 157- 161.
Liu, Y. J and Ding, H (2008): Variation in air pollution tolerance index of plants near a steel factory; implication for landscape- plant species selection for industrial areas. WSEAS Transactions on Environment and Development, 4, 24- 32.

Lowry, O. H, Rosenbrough, N. J, Farr, A. L, Randall, R. J (1951): Protein measurement with the folin phenol reagent. Journal of Biological Chemistry, 193, 265- 275.

Minsocam. Org. American Minerologist (1929): volume 14, pages 81-94. The temperatures of magmas, Espers, Larsen, Harvard University.

Mishra, C. P, Pandey, Kiran and Pandey, D. D. (2008): Effect of cement dust pollution on Safflower (Carthamus tinctorious L.). Modern J.Life Science. Vol.6\&7 (1-2): 10-30

Mishra, R.D. and Kumari, P. (2008): Effect of dust pollution on chlorophyll and characteristics of maize. Adv. Biol. Res. Vol. 26(1\&2):62-67

Mishra, M (20014): Project achievement reports; update, Nov. 2004 on demonstration of dust suppression Technology to reduce occupational and Environmental health hazards in stone crusher industries, a project study in Khurda Orissa, India by JrP, CISS (India) and PKI (USA).

Naidoo, G and Chirkoot, D (2004): The effects of coal dust on photosynthetic performance of mangrove, Avicennia marina in Richards Bay, South Africa, Environmental pollution, 127, 359366.

Patil, M. A (2001): Environmental management scenario in stone crusher industry sector and cleaner production possibilities, TERI Information Monitor on Environment Science 6, 83- 92. 
Pandey, D.D and Nand, S (1995): Effects of stone crusher dust pollution on grain characteristics of maize. Environment and Ecology, 13, 901- 903.

Pandey, A.; Tiwari, K. and Pandey, J. 2009. Atmospheric deposition of nutrients in a dry tropical urben environment of Varanasi. Proc. Of National Symposium on Environmental threat to human health in 21 st century. B. H.U., Varansi, Page53.

Pandey, D.D. and kumar, K. 1996. Impact of cement dust pollution on biomass, chlorophyll, nutrient and grain characteristics of wheat, Environment \& Ecology, 10(4): 872-875.

Pandey, D.D and Kumar, K. 2004. Effect of dust pollution on nutritional

Quality of Cynodon dactylon. Environmental \& Ecology 22 (spl. 4) ; 775-777.

Pandey, D.D. and Pandey, Kiran 2010. Effect of particulate pollutant on chlorophyll of rice leaf. Adv. Biol. Reg. 28(1): 167-168.

Pandey, D.D. and Prasad, Raghunath (2010): Effect of cement dust pollution of Zea mays. In Proceeding of Environmental pollution : A threat to living world. Edited by D.D. Pandey, Jaspal Prakashan, Patna, page 20.

Pandey, D.D. and Sinha, M. (2000): Effect of fly ash pollution on biomass, primary productivity and characteristics of grains of Maize. Environmental \&Ecology 18(3):738741.

Pandey, G., Kumar, Bhola and Pandey, D.D.2008. Effect of stone crusher dust pollution on biomass and productivity of Sesamum indicum. Environmental \& Ecology Vol.20(1): 230-231.

Prasad, S.N. Mishra, C.P. and Sinha, A.P.(2010): Effect of cement dust pollution on nutritional quality of Dichanthium annulatum. In Proc. Of National Seminar on Environmental pollution. A threat to living world. Organized by P.G. Dept. of Botony, Nalanda College, Biharsharif held on 27-28 March, 2010, Page 19.

Prajapati, S. K and Tripathi, B. D (2008): Seasonal variation of leaf dust accumulation and pigment content in plant species exposed to urban particulates pollution, Journal of Environmental Quality. 37, 865- 870.

Prasad, B. J and Rao, D. N (1981): Growth response of Phaseolus aureus plants to petro- coke pollution, Journal of Experimental Botany, 32, 1343- 1350.

Pyatt, F. B and Haywood, W. J (1989): Air borne particulate distributions and their accumulation in tree canopies, Nottingham, UK. The Environmentalist 30, 18- 23.

Rai, A, Kulshreshtha, K, Srivastava, P. K and Mohanty, C. S (2010): Leaf surface structure alterations due to particulate pollution in some common plants. Environmentalist, 30, 18- 23.

Rao, D. N (1985): Plants and Particulate pollutants. Air pollution and plants: A state of Art Report, Ministry of Environment and Forest; Department of Environment, Govt. of India, new Delhi, India.

Rao, D. N. (1971): A study of air pollution problem made to coal unloading in Varanasi, India. Academic Press of 2nd International Clean Air Congress, 235- 276.

Rao, D. N (1981): A study of air pollution problem due to coal unloading in Varanasi, India. Proceeding of International Clean Air Congress, 273- 276.

Sadhana Chaurasia, Ashwani Karwariya and Anand Dev Gupta (2014): Impact of Cement Industry Pollution on 
Morphological Attributes of Wheat (Triticum species) Kodinar, Gujarat, India, Journal of Environmental Science, Toxicology and Food Technology, 8(7), 84- 89.

Sadhana Chaurasia, Ashwani Karwariya and Anand Dev Gupta (2013): Effedt of cement industry pollution on chlorophyll content of some crops at Kodinar, Gujarat, India, Proceedings of the International Academy of Ecology and Environmental Science, 3(4): 288- 295

Saha, D L and Padhy, P. K (2011): Effects of stone crushing industry on Shorea robusta and Madhuca indica foliage in Lalpahari forest. Atmospheric Pollution Research, 2, 463-476.

Shashi Bhushan Sharma and Baidyanath Kumar (2015): Effects of Stone Crusher Dust Pollution on Growth Performance and Yield Status of Gram (Cicer arietinum L.) Int.J.Curr.Microbiol.App.Sci， 4(3): 971-979

Shivcoumar, R, Jayabalou, R, Swarnalatha, S, Balakrishnan, K (2006): Particulate matter from stone crushing industry: Size distribution and health effects.
Journal of Environmental Engineering- ASCF, 132, 405- 414.

Semban, T and Chandrashekhar, S (2000): Impact of crusher pollution on workers in tricky. Environment and People 7, publication society for Environment and Education.

Singh, S. N and Rao, D. N (1980): Growth on Wheat plants exposed to cement dust pollution, Water, Air and Soil pollution, 14, 241- 249.

Trivedi, M. L and Singh, R. S (1995): Reduction in protein contents in a few plants as indicators of air pollution. Pollution Research 14, 269- 273.

Verma, and Singh, S. N (2006): Biochemical and ultrastructural changes in plant foliage exposed to auto- pollution, Environmental Monitoring and Assessment, 120, 585-602.

Williams, A. J and Banerjee, S. K(1995): Effect of thermal power plant emission on the metabolic activities of Mangifera indica and Shorea robusta. Environment and Ecology 13, 914- 919.

\section{How to cite this article:}

Shashi Bhushan Sharma and Baidyanath Kumar. 2016. Effects of stone crusher dust pollution on growth performance and yield status of rice (Oryza sativa. L). Int.J.Curr.Microbiol.App.Sci. 5(5): 796-806. doi: http://dx.doi.org/10.20546/ijcmas.2016.505.080 